\title{
WOMAN SEARCHING FOR FAMILY NAFKAH IN ISLAMIC ECONOMIC VIEWS
}

\author{
Nurhadi \\ The High Islamic Education of al-Azhar Pekanbaru Riau \\ email: alhadijurnal@gmail.com
}

\begin{abstract}
This article focuses on the discussion of Islamic and economic views on women making a living for families (husbands and children). This phenomenon is already popular in Indonesian society, with many female workers (TKW) making a living or working abroad for the sake of family survival (husband and children), this is also reinforced by soap opera shows on private national television titled "The world is upside down" as a manifestation of the socio-economic facts of the Indonesian family today which is visualized as soap operas. This is a big question mark for socio-economic observers and practitioners of sakinah or Muslim families. In general, the main task of making a family living in Islam is assigned to the man (husband). Although it is justified that women (wives) earn a living (working) to help the family economy if the husband's income is insufficient for family needs, provided that the woman in work does not bring shame, slander and harm to herself and the continuity of her household, and can maintain her honor by always covering aurat and keep away from things that produce salaries are not halal (haram). So a woman who is a family breadwinner in the view of Islamic economics is permitted, but that as an alternative to maintaining survival and domestic life with her husband and children, also does not violate her nature as a wife and mother for her children. This analysis arises because economic activity is a social activity, so the social is very closely related to the economy, also the Islamic economy and socioeconomic family in Islam.
\end{abstract}

Keywords: women, search, livelihood, family, Islamic economy. 
الملخص: يركز هذا المقال على مناقشة الآراء الإسلامية والاقتصادية حول النساء اللائي يكسبن

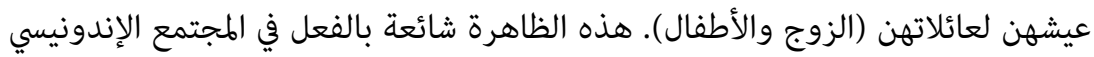

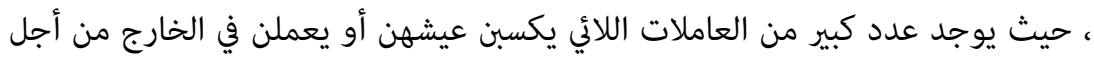

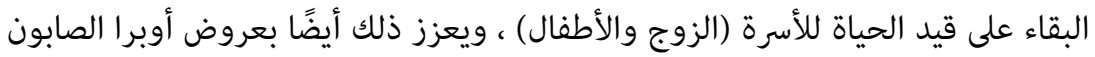

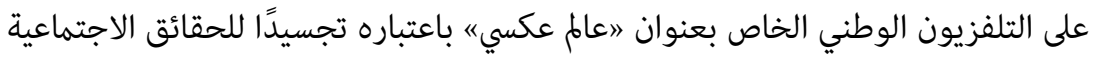

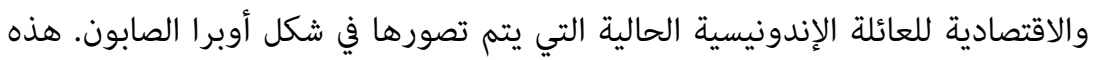

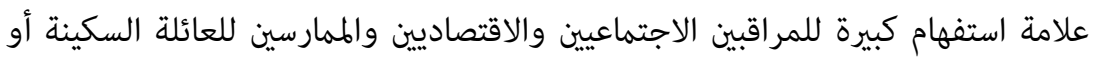

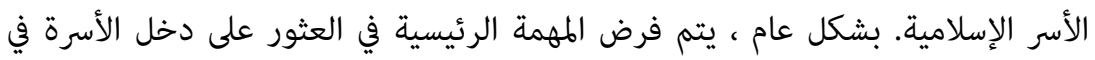

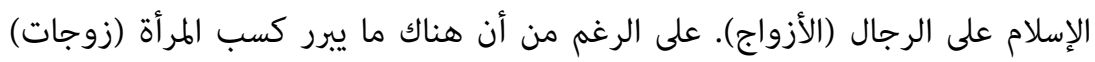

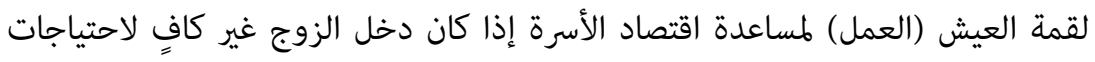

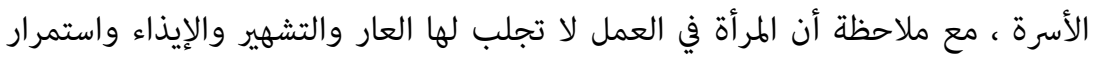

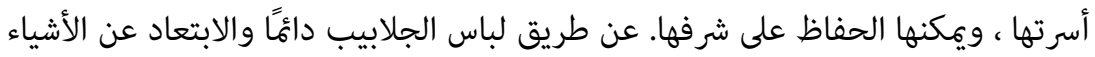

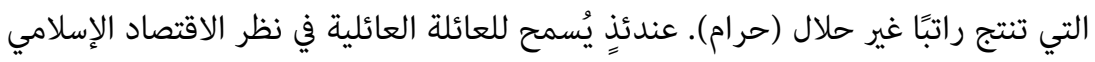

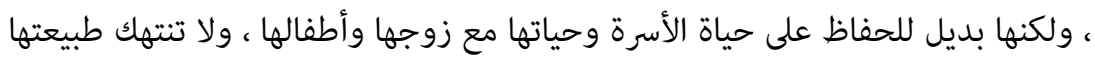

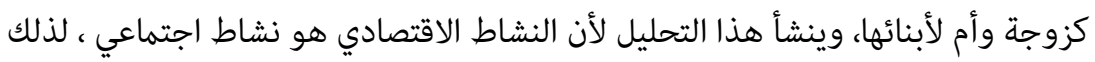

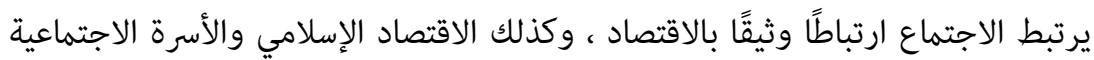

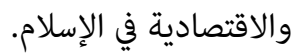

Abstrak: Artikel ini memfokuskan pembahasan pandangan Islam dan ekonomi tentang perempuan mencari nafkah untuk keluarga (suami dan anak-anak). Phenomena seperti ini sudah popular di masyarakat Indonesia, dengan banyaknya tenaga kerja wanita (TKW) yang mencari nafkah atau berkerja ke luar negeri demi kelangsungan hidup keluarga (suami dan anakanaknya), hal ini dikuatkan pula dengan tayangan sinetron di televisi nasional swasta yang berjudul "dunia terbalik" sebagai perwujudan fakta sosial ekonomi keluarga masyarakat Indonesia saat ini yang divisualkan berbentuk sinetron. Hal ini menjadi tanda tanya besar bagi pengamat sosial ekonomi dan praktisi keluarga sakinah atau keluarga Islam. Secara umum, tugas pokok dalam mencari nafkah keluarga dalam Islam dibebankan pada laki-laki (suami). Kendati dibenarkan perempuan (istri) mencari nafkah keluarga (berkerja) membantu perekonomian keluarga jika memang pendapatan suami tidak mencukupi untuk 
kebutuhan keluarga, dengan catatan bahwa perempuan tersebut dalam berkerja tidak mendatangkan aib, fitnah dan mudarat bagi dirinya dan kelangsungan rumah tangganya, serta dapat menjaga kehormatannya dengan selalu menutup aurat dan menjauhkan dari hal-hal yang menghasilkan gaji tidak halal (haram). Maka wanita pencari nafkah keluarga dalam pandangan ekonomi Islam dibolehkan, namun itu sebagai alternatif untuk mempertahankan kelangsungan hidup dan kehidupan rumah tangga dengan suami dan anak-anaknya, juga tidak melanggar kodratnya sebagai istri dan ibu bagi anak-anaknya. Analisis ini muncul karena kegiatan ekonomi merupakan kegiatan sosial, maka sosial sangat erat kaitanya dengan ekonomi, juga ekonomi Islam dan sosial ekonomi keluarga dalam Islam.

\section{INTRODUCTION}

When black smoke enveloped the faces of women in the Jahiliyah era, the light of Islam shone on it. Islam places women in proportion by recognizing women's humanity and eroding the darkness experienced by women throughout history and guaranteeing women's rights. To explain the position of women in Islamic law, the legal basis that must be held is the two main sources of Islamic law, namely the Qur'an and Sunnah. From these two sources, certain principles are obtained to see the position of women in Islam. However, we must understand that the principles outlined by the Qur'an and Sunnah are sometimes practiced differently by Muslims in their daily lives. In fact, it must also be realized that the verses of the Qur'an and the traditions of the Prophet who actually voiced issues of justice and equality are often understood as the opposite, so that in Muslim thinkers (ulama) differences of opinion arise in various Islamic issues, including Islamic law. In a position like this, the Qur' an provides a resolute solution, that if between us there are differences of opinion then we should again refer to Allah Almighty and the Messenger of Allah to decide the case as stated in the Qur'an surah al-Nisa': 59. ${ }^{1}$ Therefore,

1 It means: "O you who have believed, obey Allah and obey the Messenger and those in authority among you. And if you disagree over anything, refer it to Allah and the Messenger, if you should believe in Allah and the Last Day. That is the best [way] and best in result. Departemen Agama Republik Indonesia, al-Qur 'an and Translation (Semarang: Toha Putra, 2015), 128. 
when different societies develop different opinions about the rights and obligations of women, for example, then we must refer to the provisions in the Qur'an and the Sunnah of the Prophet Muhammad.

Women are part of Islam and women have an important position in Islam. Islam highly respects women, Islam also considers women and men to be equal. where Islam strongly encourages education for women, and women have a social role in the wider community as evidenced by the existence of public figure women in the fields of: politics, economics, health and so on. Women also have a role in the order of care in their households, because women are leaders in their households explained in the words of the Prophet. ${ }^{2}$

Customs and partriarchal cultures have parsed marginal women, male hegemony as superiority beings who regard women as subordinates of men. ${ }^{3}$ Not only that, the interpretation of the ulamas has tended to be misogynistic (cornering women) and thick with the color of gender bias. Therefore, when religion contributes to the legitimacy of partisan kinship and the pattern of sexual division of labor, then gender discourse will naturally come into contact with religious issues. ${ }^{4}$ Religion has been used as a proposition to reject the concept of equality between men and women, even religion is considered as one of the factors that causes the perpetuation of women's stat us quo as the second sex. ${ }^{5}$

Islam does not recognize discrimination or packaging of one particular group. All people have the same position before God Almighty, both men and women. The difference is the level of faith. In the Islamic world, women have a noble position. Even when in heaven, world women who believe are better and prettier than angels. Because, it is not the same between people who work hard, worship, are subject to taklif (duty of duty) as well as calamities or tests that

2 Halimah Sya'diyah, Perempuan dalam Perspektif Islam (Purwokerto: Fakultas Studi Islam, Universitas Muhammadiyah, 2014), iv.

3 Abbas, 'Perempuan dalam Pandangan Agama (Studi Jender dalam Perspektif Islam)', Muwazah 4, no. 2 (2013): 189-190.

4 Ali Yafie, Kemitraan Perempuan-Laki-laki: Agama Islam di Bainar (Red), Wacana Perempuan dalam Keindonesiaan dan Modernitas (Yogyakarta: Cidesindo, 2011), 141.

5 Nasaruddin Umar, Kebijakan Kesetaraan Gender dalam Perspektif al-Qur'an (Jakarta: Paramadina, 2010), 1. 
must be faced with creatures created specifically to inhabit heaven without having to face all that. ${ }^{6}$

The issue of women's emancipation or gender equality is often used by certain parties to discredit Islam. In general it is said that there has been discrimination between men and women in Islamic teachings. Seeing the teachings of Islam, anyone must be careful and thorough in understanding it. To know the teachings of Islam, people must be able to see it correctly in the parts that exist in Islamic teachings in order to understand it objectively. In Islam there are parts that are absolute and some that are relative. The absolute are the parts which are the basic teachings (ushul) that are in the Qur'an and the Sunnah. Whereas the relative is part of the teachings which are the result of human thought (ijtihad) about details and elaboration (furu ') about how to implement these basic teachings. ${ }^{\text {? }}$

The problem of differences between men and women is often referred to as gender. The word gender is a vocabulary drawn from English gender which means gender. Terminologically, gender is interpreted as "mental and cultural interpretation of sex differences, namely male and female". "Gender is usually used to indicate the division of labor that is considered appropriate for men and women". It could also be said, gender is a concept used to identify differences in men and women in terms of socio-cultural aspects. ${ }^{8}$

The most noticeable progress in the world of education today is the increasing opportunities for women to enter the world of education. All levels and types of free education are entered by women. Almost no more special education is found for men except education in pesantren. All majors and study programs, from the humanities to open engineering are entered without distinguishing the sexes. ${ }^{9}$

The freedom to obtain this education, it turns out, it does not provide opportunities for women to win the competition in gaining employment. This is because education, which is considered a

6 Muhammad Sarbini, 'Hak-hak Wanita dalam Fiqih Islam', al-Mashlahah: Jurnal Hukum Islam dan Pranata Sosial Islam 5, no. 09 (2017): 609-627.

7 Zainul Muhibbin, 'Wanita dalam Islam', Jurnal Sosial Humaniora 4, no. 2 (2011): 109-121.

8 Muhibbin, 110.

9 Nelsi Arisandy, 'Pendidikan dan Karir untuk Wanita dalam Perspektif Islam', Marwah Journal XV, no. 2 (2016): 125. 
passport to get a job, has created a new caste in modern life for women. People are considered capable, capable, and worthy of being accepted in a job by looking at their education. Plus, success in the education process, or academic ability symbolized by the Grade Point Average (GPA) is used as a barometer for consideration in accepting prospective workers. ${ }^{10}$

This condition has shifted the competition to get a job into a feud to get a place in the world of education. Seizing opportunities in the world of education is far more objective, scientific, and not discriminatory towards gender. Because the competition for education is more determined by academic ability, the position of women is greatly benefited. Since childhood, girls' activities are often controlled compared to boys, limited to going out of the house, so they have plenty of time at home and are usually used to study. So it is only natural that girls' learning outcomes are better than boys. Seven or eight of the top 10 in schools are actually dominated by girls. Not surprisingly, many faculties today are flooded with female students. They can defeat male domination. ${ }^{11}$

Along with the enormity of the discourse about liberation and empowerment of women, today the phenomenon of gender equality has become an important issue in every religion, including Islam. ${ }^{12}$ In the midst of an atmosphere of female domestication and patriarchal domination, feminists sought to expel women from the center of men. The term used by Munawar-Racham for this behavior is "excentralism". Women must be freed from their cultural roles so far as "kanca wingking". 13

One of the thoughts that contributes to gender relations is the existence of physical-biological differences between men and women. The difference is seen among others in the accessories of

${ }_{11}$ Arisandy, 125.

${ }^{12}$ Ajat Sudrajat, 'Beberapa Persoalan Perempuan dalam Islam', Prodi Ilmu Sejarah FISE UNY, 1-16.

${ }^{13}$ Budhy Munawar Rahman, 'Rekonstruksi Fiqh Perempuan dalam Konteks Perubahan Usia', in Rekonstruksi Fiqh Perempuan, ed. M. Hajar Dewantoro and Asmawi (Yogyakarta: Penerbit Ababil, 2006), 24-25. Kamla Bashin, Menuntut Patriarki: Pengantar Isu Dominasi Terhadap Perempuan (Yogyakarta: Bentang, 2007), v. 
reproductive organs, such as genitals and breasts. ${ }^{14}$ The biological reality that distinguishes between men and women has given rise to two theories, namely nature theory and nurture theory. ${ }^{15}$

In the al-Qur' an there are 114 letters, one of which is the letter al-Nisa' located after the letters al-Baqarah and Ali-Imran. Thus women's problems are also found in other verses in the Qur'an, in which discuss issues around women, from objective to negative positive. ${ }^{16}$ This shows how important and noble the position of women in Islam, where openly it has been included and named in one of the letters of the Qur'an, the holy book of Islam. Rasulullah Saw. said: "Heaven under the sole of the mother's foot", in it contained another understanding, that women are potential human resources to give birth to heaven (welfare). If these resources are destroyed through good packaging and aiming for certain interests, then women will no longer have heaven in the soles of their feet, but hell. ${ }^{17}$

The position of women in society is not a new issue and also not something that has been fully determined. The position of Islam in this matter has become the focus of the Western world with a very lack of objectivity. Islamic teachings come from the Qur'an and the Sunnah (hadith). The Qur' an and Hadith clearly and without bias become authentic sources of all matters relating to Islam. ${ }^{18}$

The world of work itself, especially in western countries that tend to echo the term gender equality, prioritize female workers more than men with evidence of more numbers of female migrant workers (TKW), the data can be seen in Kompas Com, Minister of Manpower said TKI was up to at the end of 2017 as many as 9 million. ${ }^{19}$ Likewise, those who were shunted by the World Bank Data noted that there were 9 million migrant workers or Indonesian migrant workers (TKI)

${ }^{14}$ Nasaruddin Umar, Argumen Kesetaraan Jender Perspektif al-Qur'an (Jakarta: Paramadina, 1999), 38-40.

${ }^{15}$ Umar, Argumen Kesetaraan Jender Perspektif Al-Qur'an, xxi.

${ }^{16}$ Ulya Kencana, 'Perempuan dalam Pandangan Agama dan Bangsa', An Nisa'a Journal 7, no. 2 (2012): 87-102.

${ }^{17}$ Abdullah A. Djawas, Dilema Wanita Karier; Menuju Keluarga Sakinah (Yogyakarta: Ababil, 2010), 21.

${ }^{18}$ Jamal A. Badawi, Posisi Perempuan dalam Islam (e-Book Maktabah Raudhah al-Muhibbin, 2008), 3.

${ }^{19}$ Andri Donnal Putera and Aprilia Ika, 'Ini Adalah Data Pekerja Asing di Indonesia dan Perbandingannya dengan Pekerja Migran Indonesia di Luar Negeri', Kompas.com, 2018. 
in various countries. ${ }^{20}$ Of the total 9 million migrant workers as much as $60 \%$, this can be taken from data from 2013-2015 and 2016. ${ }^{21}$ At the same time it is supported by a portrait of the "Reverse World" soap opera which describes the family's socio-economy, in which the wife earns a living abroad for her family (husband and children).

\section{WOMEN IN ISLAM}

Al-Qur'an shows the existence of gender equality. He found five variables that support his opinion, namely: 1) Men and women alike as servants. This can be seen for example in QS. al-Hujurat: 13 and al-Nahl: 97; 2) Men and women as caliphs on earth. This can be seen in QS. al-Baqarat: 30 and al-An'am: 165; 3) Men and women accept primordial agreements as seen in QS. Al-A'raf: 172; 4) Adam and Eve were actively involved in the cosmic drama. This clarity is seen in QS. al-Baqarat: 35 and 187, al-A'raf: 20, 22, and 23; and 5) Men and women have the potential to achieve as seen in QS. Ali 'Imran: 195, al-Nisa': 124, al-Nahl: 97, and al-Mu'min: $40 .{ }^{22}$

According to Mustafa al-Siba'i, the position of women in Islam is as high as the position of men. According to him, Islam regulates the principle similarity between men and women in at least twelve matters which cover the humanitarian, social, and property rights fields. The twelve principles are: 1) men and women alike in terms of humanity; 2) Islam eliminates the curse given by pre-Islamic religious experts to women. Islam stipulates that the punishment imposed on Adam, out of heaven, does not originate from Eve alone, but from them both; 3) Women have the ability to be religious and to enter heaven if they do good and will be tortured if they do evil, just like men; 4) Islam erodes pessimism and sadness at the time of the birth of a daughter,

${ }^{20}$ Adhitya Himawan, 'PSI: TKA Hanya 1,4 Persen Dibandingkan 9 Juta Buruh Migran di Luar Negeri', Suara.com, 5 February 2018.

${ }^{21}$ Badan Nasional Penempatan dan Perlindungan Tenaga Kerja Indonesia (BNP2TKI), 'Jumlah Pekerja Migran Indonesia Berdasarkan Jenis Kelamin', Beritagar.id, 2015-2016.

${ }^{22}$ Umar, Argumen Kesetaraan Jender Perspektif al-Qur'an, 248-269. Yusuf Al-Qardawi's opinion concluded from the verses of the Qur' an that women have the position, life, understanding, and thinking like men. Women are burdened (taklif) like men. All his goodness will be appreciated, both in the world and in the hereafter, like humans. The cry of the Koran is directed at men and women. But biologically (naturally) women and men are not all the same, there are differences between the two in certain respects. 
like the traditions of the Arabs before Islam; 5) Islam prohibits the burial of girls in living conditions and threatens violently against the perpetrators; 6) Islam commands that respect women as daughters, wives, or mothers; 7) Islam recommends that women be taught like men; 8) Islam provides rights for women in inheritance, both as a mother, wife, or daughter, for those who are adults or still small, even those who are still in the womb; 9) Islam regulates the rights of husbands and makes women's property the same as men's property, the position of men as leaders in the household is not dictatorial and unjust; 10) Islam regulates the problem of divorce, prevents arbitrary traits and self-winning actions from men; 11) Islam limits polygamy and stipulates that the number of wives can only be up to four; and 12) before adulthood, the woman is determined to be in the care of her guardian, and the guardian's power is in the form of maintaining and educating power and observing all her needs and developing her property. After the child is mature, Islam stipulates that he has full rights and has the perfect ability to use his assets like men. ${ }^{23}$

According to Quraish Shihab that a woman has its own rights, which are among others: a) Rights outside the home b) Rights and learning obligations c) Rights in the political field. ${ }^{24}$

According to Jalaluddin Rachmat that women are in accordance with their feminine nature. Islam establishes its roles in various statuses. Namely, women as mothers, wives, children and as da'iyah. Mother's status is the foremost, therefore women have the most decisive role in people's lives. The stat us of the wife strengthens the family institution. The status of the child demands the maintenance of good morals and the status da'iyah requires women to appear in the community as a pioneer of liberation, reformation and progress. Islam sees the dilemma faced by modern women as a violation of the role assigned by Islam. He further said that women have the same rights as men. But the nature of womanhood that she possessed

${ }^{23}$ Musțafā al-Sibā'iy, al-Mar'ah Bayn al-Fiqh wa al-Qanūn (Beirut: al--Maktab al-Islamiy, 2011), 38-48.

${ }^{24}$ Muhammad Qurais Shihab, Mendasarkan Al-Quran: Fungsi Dan Peran Wahyu Dalam Kehidupan Komunitas (Bandung: Mizan, 2006), 303. Muhammad Qurais Shihab, Wawasan al-Qur'an: Interpretasi Maudhu'i Tentang Isu-isu Umat (Bandung: Mizan, 2017), 205. 
distinguishes the role of women in the social field of Islam regulating the role of the woman. ${ }^{25}$

The study of Islamic Jurisprudence has provided a detailed description of women's rights in all aspects of their lives, both general and special rights. Rights that are widely discussed in Islamic jurisprudence are rights related to law, because this is indeed the realm of Islamic jurisprudence. Women's rights that are widely discussed in Islamic jurisprudence include: 1) Prayer rights in congregation; 2) Right to determine companion choices; 3) Jima' rights'; 4). Mahar Rights; 5) Livelihood Rights; 5) Inheritance; 6) Sale and purchase rights or business; 7) Hak Baiat. All of these rights illustrate all the chapters in the legal problems inherent in women's lives, both in the public sector, worship midwives and in the household and financial fields. ${ }^{26}$

Many works by thinkers and scholars have outlined the position of Islam regarding the position of women in society, there are several aspects, including: 1) Spiritual Aspects; 2) Social aspects, including: as children and adults, as wives and as mothers; 3) Economic Aspects; 4) Political Aspects. ${ }^{27}$

\section{OBLIGATION TO SEEK FAMILY INCOME IN ISLAM}

Before discussing further about who has the right to earn a living in a family (family), the writer will present a verse relating to this matter, namely al-Qur' an surah al-Nisa: 34:

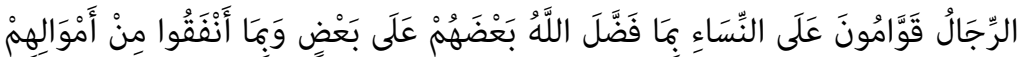

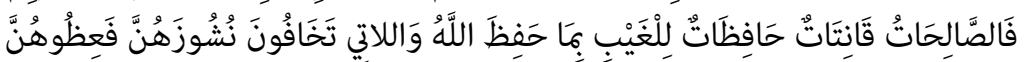

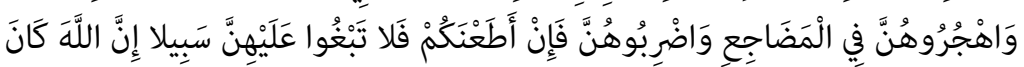
عَلِيَّا كَبِيًَا

Meaning: The men are leaders for women, because Allah has exaggerated a portion of them (men) over others (women), and because they (men) spend part of their wealth. Therefore, a righteous woman is one who obeys God and takes care of herself when her husband is absent, because God has cared for them. the

${ }^{25}$ Jalaluddin Rahmat, Islam Alternatif: Ceramah di Kampus (Bandung: Mizan, 2001), 137.

${ }^{26}$ Sarbini, 'Hak-hak Wanita dalam Fiqih Islam', 613-26.

${ }^{27}$ Badawi, Posisi Perempuan dalam Islam, 6-14. 
women you worry about nusyuz, then advise them and separate them in their beds, and beat them. then if they obey you, then don't look for a way to trouble it. Allah is Most High, Most Great.

From the verse above, there is a stereotypical view that leadership in the household is in the hands of a husband (male). From this domestic leadership it then widened to the public sector, which also placed men as leaders. This view has encouraged feminists to look back on the meaning of the verse, because it was seen to contain a gender-biased interpretation.

Understanding the verse, commentators such as Zamakhsyari and Alusi state that in a household, a husband (male) is the leader of his wife. The key sentence on which they are based is "al-rijal qawwäm 'ala al-nis̄",". By Zamakhsyari, the sentence is interpreted as "the males function as those who govern and forbid women as leaders who function towards their people". With different editors Alusi stated the same thing with Zamakhshari that "the task of men is to lead women as leaders lead their people, namely by orders, prohibitions, and the like". ${ }^{28}$

The reason Zamakhsyari is why men lead women in the household because: first, the excess of men over women. The strength of the man is the excess of reason, determination, willpower, physical strength, ability to write, ride a horse, archery, become a prophet, cleric, head of state, imam salat, jihad, adhan, sermon, i'tikaf, testimony in hudud and qisas, get asabah in inheritance, guardian marriage, drop talak, declare ruju, may be polygamous, the name of the child is attributed to him, bearded and wear a turban. Second, men pay dowry and spend a family income. ${ }^{29}$

Meanwhile, Alusi argued that the reason was based on the existence of two inherent characteristics of men, namely the nature of wahbi and kasabi. Wahbi is the advantage that is obtained by itself (given) from God, without effort; while kasabi is an advantage that is the result of effort. According to Alusi the verse does not explain what are the advantages of men over women. According to him, this

${ }^{28}$ Sudrajat, 'Beberapa Persoalan Perempuan dalam Islam', 6.

${ }^{29}$ Yunahar Ilyas, Feminisme dalam Interpretasi al-Qur'an Klasik dan Kontemporer (Yogyakarta: Student Library, 2007), 77. 
suggests that the advantages of men over women are very clear, so they no longer need detailed explanations. ${ }^{30}$

According to Quraish Shihab the verse above is the legitimacy of the leadership of men (husbands) towards all their families in the field of domestic life. According to him this leadership actually does not revoke the rights of the wife in various aspects, including the ownership rights of personal property and management rights even without the husband's consent. In his opinion, leadership is a necessity, because the family sees it as the smallest social unit that requires a leader. The reason he stated, that the husband or man has physical and psychological traits that can better support the success of the leadership of the household compared to the wife. In addition, the husband (male) has an obligation to provide for his wife and all members of his family. ${ }^{31}$ To strengthen his opinion, Quraysh Shihab quoted QS. al-Baqarah: 228:

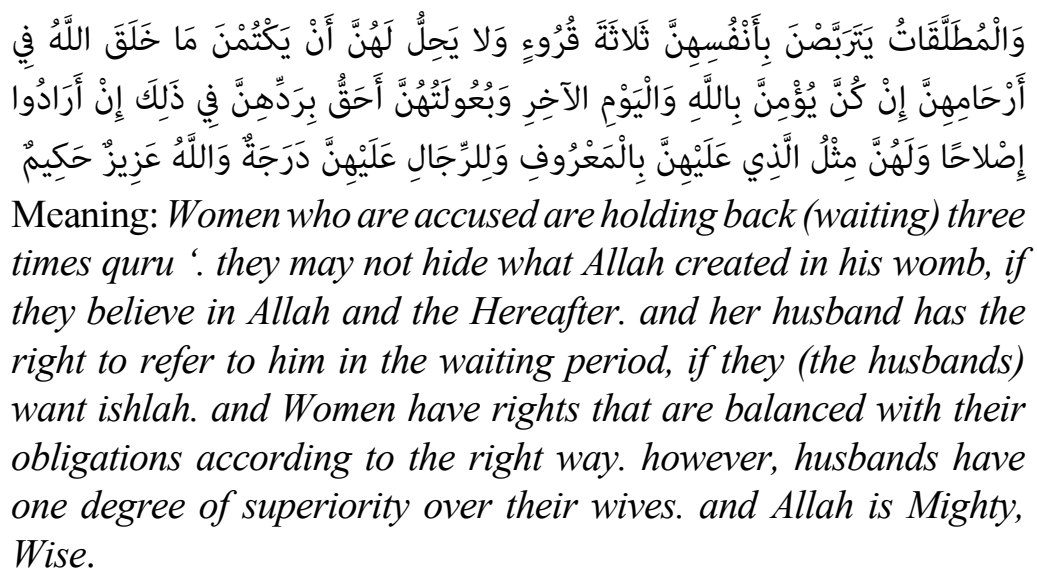

Such are the views of some interpreters about the concept of household leadership as they understand from al-Nisa: 34. They agree in their interpretation that men (husbands) are female leaders (wife) for two reasons, namely: because of the superiority of men over women, and because of the income they spend for the needs of their wives and other households. In another perspective, the above verse is understood differently by feminists. According to Asghar Ali Engineer as quoted by Ajat Sudrajat, for example, it is argued

\footnotetext{
${ }^{30}$ Ilyas, 77.

${ }^{31}$ Shihab, Wawasan al-Qur'an: Interpretasi Maudhu'i Tentang Isu-Isu Umat,
} 310. 
that the verse al-Nisa: 34 should not be understood apart from the social context at the time the verse was revealed. According to him, the social structure in the era of the prophet did not really recognize equality between men and women. Therefore it is not permissible to take a view that is solely theological, but must use a socio-theological view. ${ }^{32}$

In Asghar's view, male superiority is not gender superiority, but in the form of functional excellence, because men earn a living and spend their wealth on women (and families). The social function carried by men is balanced with the social function carried out by women, namely doing domestic tasks in the household. The reason is because women at that time were still very low on social awareness and domestic work as a duty of women. While men see themselves superior because of their power and ability to make a living and spend it on women. ${ }^{33}$ Contrast to Asghar, Aminah Wadud and he approved men as leaders of women in the household. However, in this case he provides two conditions, namely if men have or are able to prove their strengths, and if men support women by using their property. ${ }^{34}$

A different opinion about the interpretation of the verse above was also stated by Masdar F. Masudi, in his book, ${ }^{35}$ by quoting Jalalain's interpretation, the word qawwām 'ala al-nis̄a', is not merely interpreted by mastering or culturing women, but can also be interpreted with a female support or reinforcement. ${ }^{36}$ Because this meaning is found in surah al-Nisa: $135^{37}$ and al-Maidah: $8 .{ }^{38}$ So that

${ }^{32}$ Asghar Ali Engineer, 'Perempuan dalam Syari'ah: Perspektif Feminis dalam Interpretasi Islam', Jurnal Kebudayaan dan Ilmu Pengetahuan Ulumul Qur'an V, no. 3 (1994): 61.

${ }^{33}$ Engineer, 62. Sudrajat, 'Beberapa Persoalan Perempuan dalam Islam', 8.

${ }^{34}$ Amina Wadud, Qur'an Menurut Wanita: Meluruskan Bias Jender dalam Tradisi Tafsir, trans. Abdullah Ali (Jakarta: PT. Serambi Ilmu Semesta, 2011), 93-94.

${ }^{35}$ Masdar F. Mas'udi, Islam dan Hak Reproduksi Perempuan: Dialog Pemberdayaan Fiqh (Bandung: Mizan, 2010), 61-62.

${ }^{36}$ Imam Jalalain, Tafsir Jalalain (Mesir: Maktabah ilmiyah,), 76. Sudrajat, 'Beberapa Persoalan Perempuan dalam Islam', 9.

${ }^{37}$ Which means: "O you who believe, be truly upholding justice, be a witness of God even against yourself or your father and relatives. If he is rich or poor, then God knows the benefits better, so don't follow your desires because you want to stray from the truth, and if you come back (words) or are reluctant to be a witness, then surely Allah is All-Knowing everything you do".

${ }^{38}$ Which means: "O you who believe, let you. People who always uphold (the truth) because of Allah, testify fairly. And do not let your hatred towards others 
the verse means "men are reinforcement and support for women with (not because of) one advantage over the other and with (not because of) the livelihood that they give". With this understanding, the attitude of the husband (male) to the wife (woman) is not "mastered" or "dominated" and tends to force, but support and protect. The above understanding is more in line with the principle of mu' asyarah bil ma'ruf (QS. al-Nisa: 19) ${ }^{39}$ and the principle of mutual protection (QS. al-Baqarah: $187 . .^{40}$

From the description above about the position of men as leaders for families and women, the obligation to make a living in Islam is men as the head of the family. But according to Masdar F. Mas'udi, if a husband really can support him in financing family life and prove his strengths in front of his wife and children (family), then the man (husband) is the breadwinner in Islam, but if not, women (wives) will appear in front to support and earn a living for the family as proof of obedience and obedience to their husbands, for the survival and life of their families (husbands and children). The meaning of women is justified in going out of their homes to make a living if their husbands really cannot meet the needs of the family according to the Shari'a, such as being sick, too old and other uzhur, this is according to QS. al-Baqarah: 187 surah above. However, there is something that needs to be underlined that if there are no worries there will be things that can damage him and his family.

Men in Islam are fully responsible for maintaining their wives, children and in some cases families in need, especially women. This obligation is not released or reduced due to the wealth of his wife or

encourage you to act unjustly, this is valid, because justice get closer to godliness, and fear God, surely Allah knows what you are doing".

${ }^{39}$ Which means: "O you who believe, it is illegal for you to forcibly destroy women and not cause trouble for them to take back some of what you have given to them, unless they do real abominable work, and associate with them properly. then if you don't like them, (be patient) because maybe you don't like something, even though God gave him a lot of good ".

${ }^{40}$ Which means: "Permitted you on the eve of the fasting month to mix with your wife; it is clothing for you, and you are also clothing for them. God knows that you cannot restrain your desires, therefore God forgives you and forgives you. So now intervene hands with them and follow what God has ordained for you, and eating, drinking, until the white thread of the black thread, for you, is dawn fasting until (coming) night, (but) does not disturb them, when you give in the mosque "That is the prohibition of God, so do not approach it. Thus Allah explains His verses to humans, so they will be afraid". 
because of the income earned by his wife from work, rent, profit, or other halal income. ${ }^{41}$

The obligation to make a living for families in Islam is abundant to men as heads of families and leaders in the household. So it is unfortunate as a man if the opposite is true, namely his wife who earns a living for her and her children, this is a disgrace and disgrace which is quite humiliating for men, let alone under the control of a woman (wife) in the household, this is the most naïve era for men to seek worship from earning a living for the family, it is natural that there is a term "the world has turned upside down".

\section{WOMEN WORK FOR THEIR FAMILIES IN VIEW OF ISLAMIC ECONOMICS}

Regarding the rights of women to work, it must be emphasized beforehand that Islam sees its duty in society as mother and wife as a very sacred and important role. No child helper or nurse can replace the duty of a mother as a child educator in times of growth with complex freedoms and raising them carefully. This noble and vital task, which broadly shapes the fut ure of the nation, cannot be said to "do nothing". 42

However, none of the provisions in Islam prohibit women from working when there is a need for it, especially in jobs that are in accordance with their womanhood and where the community needs them more. Examples of this profession are nurses, teachers (especially for children) and treatment. Furthermore, there is no limit to taking advantage of women's special expertise in any field. Even in a position as a judge, where there is a tendency to doubt a woman's ability in that position given her natural emotional nature, we find before that scholars such as Abu Hanifa and al-Tabari confirmed this was not why. ${ }^{43}$

With regard to women working to earn a living for the family according to the Islamic economy, then before concluding, the author felt the need to explain a little at the time of the Prophet and friends of women (wives) at that time. For example Umm Salamah (wife

\footnotetext{
${ }^{41}$ Badawi, Posisi Perempuan dalam Islam, 12.

${ }^{42}$ Badawi, 12-13.

${ }^{43}$ Badawi, 12-13.
} 
of the Prophet), Shafiyah, Laila al-Ghaffariyah, Ummu Sinam alAslamiyah, and others, were recorded as figures involved in warfare. ${ }^{44}$

Narrated from Ibn Umar he said, Rasulullah Sallallaahu 'Alaihi wa Sallam said: "Do not prevent women from going to the mosque, while their home is better for them" (Reported by Abu Dawud and Ibn Khuzaimah and this lafadz from Abu Dawud ). From Abdullah bin Umar he said, the Prophet Saw. said: "If one of you asks for permission (to worship in the mosque) then don't prevent it" (Reported by alBukhari and Muslim, this lafadz is from al-Bukhari). Narrated from Abu Hurairah he said, verily the Prophet Saw. said: "Do not prevent women from going to the mosque, but let them come out without fragrance" (Narrated by Abu Dawud).

In the mosque there are certainly many men. Even in the Prophet's Mosque, there is no hijab to separate men and women. So it is not appropriate to forbid women from going to the mosque, let alone to work outside the home. Women working and doing activities outside the home have been exemplified by the wife of the Prophet Muhammad, namely Khadijah and 'Aisha. Khadijah is a businessman who often travels far. ${ }^{45}$

Even after marrying the Prophet Muhammad, Khadijah's wealth was used in part to support da'wah. It is conceivable, if Khadijah did not work outside the home, what about Islamic preaching in the early days?. While Aisha was a woman who was actively involved in a number of the Prophet's activities. While the Prophet Muhammad was still alive, 'Aisha was often involved in a number of war operations outside Medina. ${ }^{46}$

After the Messenger of Allah, 'Aisha actively taught the teachings of Islam to her friends. In a way, "Aisha was the teacher of the friends. In fact, 'Aisha had led troops in the Jamal War. From the camel, 'Aisha issued an attack order to her soldiers. Beyond that, there are many types of work that can only be done by women. Some of them are like midwives and obstetricians. So it takes the role of women to work outside the home. ${ }^{47}$

${ }^{44}$ Arisandy, 'Pendidikan dan Karir untuk Wanita dalam Perspektif Islam', 132.

${ }^{45}$ Ahmad Sarwat, 'Haramkah Wanita Berkarir dan Bekerja di Luar Rumah?', Rumah Fiqih Indonesia, 2019.

${ }^{46}$ Sarwat.

${ }^{47}$ Sarwat. 
The wife of the Messenger of Allah, Khadidjah r.a is a woman active in the business world. He was a career woman figure for the first time in Islamic history even the Messenger of Allah had committed a mudharabah (profit sharing contract) contract with him. ${ }^{48}$

Sayyidah Khadijah also carried out export-import of trade commodities internationally. His business caravan stretched from the land of Yemen to the land of Syria, and continued to work in the summer and cold. He was among the first to eliminate barriers and open the door as wide as possible for women to enter the business world. He did business long before he married Rasulllah Saw. After marriage, her business activities were continued and blessed by her husband. Even Khadijah's business assets were very much supporting preaching in the early days. At that time, there were no reliable sources of missionary support. The only thing is from the pocket of his wife who is known as the excellent busisness women. ${ }^{49}$

Of course, it is inconceivable that as a businessman, the figure of Khadijah is an uneducated type of home woman. Because if so, how could he run his business well, while he did not have the slightest access to information behind the walls of his house. Here we can understand that even the Prophet's wife had the opportunity to leave the house to take care of her business. ${ }^{50}$

After the death of Khadijah, the Messenger of Allah married 'Aisha, a smart, young and beautiful woman whose work in the community was undoubted. His position as a wife does not prevent him from being active in the community. When the Messenger of Allah was still alive, he often went out of Medina to take part in various war operations. And after the Prophet's death, 'Aisha was the teacher of the Companions who were able to provide explanations and information about the teachings of Islam. Even 'Aisha did not want to miss to participate in the war. So that the war was called the camel war, because at that time 'Aisha took a camel. ${ }^{51}$

In addition, women at the time of the Prophet were active in various fields of work. Some worked as bridal groomers, such as Umm Salim bint Malhan who made up, among others, Shafiyah bin

\footnotetext{
${ }^{48}$ Arisandy, 'Pendidikan dan Karir untuk Wanita dalam Perspektif Islam', 132.

${ }^{49}$ Arisandy, 132.

${ }^{50}$ Arisandy, 132.

${ }^{51}$ Arisandy, 133.
} 
Huyay the wife of the Prophet Muhammad. There are also those who become nurses or midwives, and so on. Recorded as a very successful person. Likewise Qilat Ummi Bani Anmar was noted as a woman who had come to the Prophet to ask for instructions in the field of buying and selling. In the book Thabaqat Ibn Sa'ad, the story of the woman is described, where it is found among other things the message of the Prophet to him concerning the pricing of buying and selling. The Prophet gave instructions to this woman by saying: "If you will buy or sell something, then set the price you want to buy or sell, then you are given or not" (He means don't beat around the bush in bidding or offering something). ${ }^{52}$

The Prophet's wife, Zainab bint Jahsy, also actively worked until tanning animal skin, and the results of his efforts were donated. Raithah, the wife of a friend of Prophet Abdullah ibn Mas'ud, was very active at work, because her husband and child were not able to provide for the family's life. Al-Syifa ', a woman who was good at writing, was assigned by Caliph Umar r.a as the officer handling the market in the city of Medina.

The women described above are just a few of the many examples that occurred during the time of the Prophet and his companions concerning the participation of women in various fields of business and employment. In addition to those mentioned above, it should also be underlined that the Messenger of Allah gave much attention and direction to women to make the best use of their time and fill it with useful works. He said: "The best" game "of a Muslim woman inside her house is spinning/weaving" (Narrated by Abu Nu' aim from Abdullah bin Rabi 'al-Ansari). ${ }^{53}$

"Aisha r.a was reported to have said: "Spinners in the hands of women are better than spears in the hands of men." Of course not all forms and types of work that exist in the present have existed at the time of the Prophet. However, as described above, ulama finally concluded that women can do any work as long as they need it or the job needs it and as long as religious and moral norms are maintained. ${ }^{54}$

From the explanation, it can be answered that women working to earn a living for the family are permissible in the view of Islam in

\footnotetext{
52 Arisandy, 133.

53 Arisandy, 133.

${ }^{54}$ Arisandy, 133.
} 
accordance with the history of the wives of the Prophet's Messenger and the wives of his friends. Review of Islamic Law Against Wives as Main Livelihood Finders in the Family is permitted, provided it meets the requirements in Islam. The role of a wife is basically as a housewife. As a wife to her husband and as a mother to her children. A wife who also makes a living in the family. The cause of the wife is also making a living for the family; first because of economic factors, social factors, lifestyle. The wife's family conditions come to make a living in general is caused by economic factors. Islamic law does not forbid wives from earning a living as long as they are not out of Islamic law, even allowing them to help their husbands earn a living, as long as they do not neglect their responsibilities as a housewife because happiness in the family is needed by the husband's role as the head of the family and the wife as the head of the household. So as to maintain the permanence of the household by supporting the family economy by means of the wife participating in earning a family income in the view of Islamic law is justified, apalgi in the view of Islamic economics, of course also allowed. Life in the household will not be stable if the economy is shaken, this needs to be addressed, so it is necessary for the wives to join in making a family income..$^{55}$

Family is the smallest social life, then economics is a social science, of course a small social will manifest a big social. Families that are small social in the family economy will have an impact on the social economy of the community. So economics which is a social science is seen by sharia, so that the term Islamic economy appears. For this reason, the view of Islamic economics in the Islamic Shari'a framework, among which women as wives earn family income is strongly recommended, provided that the principles of Islamic economics are maintained, for example the principle of equality and justice and the principle of divinity.

But the work needs to be limited, if the knowledge of women (wives) is needed by the community, then it is necessary to work out of the dive house does not occur slander. However, if the skills and knowledge possessed by a woman (wife) are not needed by the community, then the woman (wife) who works at home is the best.

${ }^{55}$ Suharna, 'Tinjauan Hukum Islam terhadap Istri Sebagai Pencari Mata Pencaharian Utama dalam Keluarga PNS di Distrik Enrekang, Kabupaten Enrekang', Jurnal al-Qad al-Qadhau 5, no. 1 (June 2018): 50. 
Then if the husband, from the results (salary) of his job can not meet the primary needs (principal) of the family, then the wife may help work at home and outside the home. In short, women who work for a family income Islamic economic views are allowed as alternative ways of survival and household and family life as in QS. al-Jumu' ah: $10,{ }^{56}$ but not leaving family in the land of people. Then the "reverse world" soap opera where women work abroad to make a living for their families (husbands and children) is not in accordance with Islamic law and Islamic economics, this right will damage the social order of the household and will be separated from happy family elements sakinah mawaddah warahmah, according to the hadith of the Prophet about the characteristics of a happy family is his sustenance in his own country. ${ }^{57}$

\section{CONCLUSION}

Women working for a family income are permissible in the view of Islam in accordance with the history of the wives of the Prophet's Messenger and the wives of his friends. But the work needs to be limited, if the knowledge of women (wives) is needed by the community, then it is necessary to work out of the dive house does not occur slander. However, if the skills and knowledge possessed by a woman (wife) are not needed by the community, then the woman (wife) who works at home is the best. Then if the husband, from the results (salary) of his job can not meet the primary needs (principal) of the family, then the wife may help work at home and outside the home. In short, women working to earn a family income Islamic economic views are allowed as alternative ways of survival and life for households and families, but not leaving families in the land of people. Then the "reverse world" soap opera where women work abroad to make a living for their families (husbands and children) is

56 Which means: "When prayer is fulfilled, you will be scattered on earth; and seek God's grace and remember God so much that you will be lucky."

${ }^{57}$ Four cases include happiness, namely a pious woman (wife) (if for a woman, of course a pious man / husband), a spacious living area, godly neighbor, and comfortable travel. And four cases of misery are bad neighbors, bad wives (not shalihah) (if for women who make misery are jerk husbands), uncomfortable vehicles, and cramped places to live "(HR. Ibn Hibban). Imam Ibn Hibban, Al-Mawarid (Lebanon: Dar Ilmiyah), 302. Make it valid Ash-Shaykh Muqbil, al-Jami'ush Shahih, vol. 3 (Kairo: Maktbah Alamiyah), 57. Ash-Syaikh al-Albani, dalam al-Ahadith al-Shahihah Silsilah (Riyadh: Maktabah Sunnah, 2001), no 282. 
not in accordance with Islamic law and Islamic economics, this right will damage the social order of the household and will be separated from happy family elements sakinah mawaddah warahmah, according to the hadith of the Prophet about the characteristics of a happy family is his sustenance in his own country.

\section{REFERENCES}

Abbas, Abbas. 'Perempuan dalam Pandangan Agama (Studi Jender Dalam Perspektif Islam)'. Muwazah 4, no. 2 (2013).

Albani, Ash-Syaikh, al-Ahadits Ash-Shahihah Silsilah. Riyadh: Maktabah Sunnah, 2001.

al-Sibāiy, Musțafā'. al-Mar'ah Bayn al-Fiqh wa al-Qanūn. Beirut: al-Maktab al-Islamiy, 2011.

Arisandy, Nelsi. 'Pendidikan dan Karir untuk Wanita dalam Perspektif Islam'. Marwah Journal XV, no. 2 (2016).

Badan Nasional Penempatan dan Perlindungan Tenaga Kerja Indonesia (BNP2TKI). 'Jumlah Pekerja Migran Indonesia Berdasarkan Jenis Kelamin’. Beritagar.id, 20162015.

Badawi, Jamal A. Posisi Perempuan dalam Islam. e-Book Maktabah Raudhah al-Muhibbin, 2008.

Bashin, Kamla. Menuntut Patriarki: Pengantar Isu Dominasi terhadap Perempuan. Yogyakarta: Bentang, 2007.

Departemen Agama Republik Indonesia. al-Qur 'an and Translation. Semarang: Toha Putra, 2015.

Djawas, Abdullah A. Dilema Wanita Karier; Menuju Keluarga Sakinah. Yogyakarta: Ababil, 2010.

Engineer, Asghar Ali. 'Perempuan dalam Syari'ah: Perspektif Feminis dalam Interpretasi Islam'. Jurnal Kebudayaan dan Ilmu Pengetahuan Ulumul Qur'an V, no. 3 (1994).

Hibban, Imam Ibn. al-Mawarid. Lebanon: Dar Ilmiyah. 
Himawan, Adhitya. 'PSI: TKA Hanya 1,4 Persen Dibandingkan 9 Juta Buruh Migran di Luar Negeri'. Suara.com, 5 February 2018.

Ilyas, Yunahar. Feminisme dalam Interpretasi al-Qur'an Klasik dan Kontemporer. Yogyakarta: Student Library, 2007.

Jalalain, Imam. Tafsir Jalalain. Mesir: Maktabah Ilmiyah.

Kencana, Ulya. 'Perempuan dalam Pandangan Agama dan Bangsa'. An Nisa'a Journal 7, no. 2 (2012).

Mas'udi, Masdar F. Islam dan Hak Reproduksi Perempuan: Dialog Pemberdayaan Fiqh. Bandung: Mizan, 2010.

Muhibbin, Zainul. 'Wanita dalam Islam'. Jurnal Sosial Humaniora 4, no. 2 (2011): 109-120.

Muqbil, Ash-Shaykh. al-Jami' al-Shahih. Vol. 3. Kairo: Maktbah Alamiyah.

Putera, Andri Donnal, and Aprilia Ika. 'Ini Adalah Data Pekerja Asing di Indonesia dan Perbandingannya dengan Pekerja Migran Indonesia di Luar Negeri'. Kompas.com, 2018.

Rahman, Budhy Munawar. 'Rekonstruksi Fiqh Perempuan dalam Konteks Perubahan Usia'. In Rekonstruksi Fiqh Perempuan, edited by M. Hajar Dewantoro and Asmawi. Yogyakarta: Penerbit Ababil, 2006.

Rahmat, Jalaluddin. Islam Alternatif: Ceramah di Kampus. Bandung: Mizan, 2001.

Sarbini, Muhammad. 'Hak-hak Wanita dalam Fiqih Islam'. alMashlahah: Jurnal Hukum Islam dan Pranata Sosial Islam 5, no. 09 (2017).

Sarwat, Ahmad. 'Haramkah Wanita Berkarir dan Bekerja di Luar Rumah?’ Rumah Fiqih Indonesia, 2019.

Shihab, Muhammad Qurais. Mendasarkan al-Quran: Fungsi dan Peran Wahyu dalam Kehidupan Komunitas. Bandung: Mizan, 2006. isu Umat. Bandung: Mizan, 2017. 
Sudrajat, Ajat. 'Beberapa Persoalan Perempuan dalam Islam'. Prodi Ilmu Sejarah FISE UNY.

Suharna. 'Tinjauan Hukum Islam terhadap Istri Sebagai Pencari Mata Pencaharian Utama dalam Keluarga PNS di Distrik Enrekang, Kabupaten Enrekang'. Jurnal al-Qad al-Qadhau 5, no. 1 (June 2018).

Sya'diyah, Halimah. Perempuan dalam Perspektif Islam. Purwokerto: Fakultas Studi Islam, Universitas Muhammadiyah, 2014.

Umar, Nasaruddin. Argumen Kesetaraan Jender Perspektif alQur'an. Jakarta: Paramadina, 1999.

- Kebijakan Kesetaraan Gender dalam Perspektif al-Qur'an. Jakarta: Paramadina, 2010.

Wadud, Amina. Qur'an Menurut Wanita: Meluruskan Bias Jender dalam Tradisi Tafsir. Translated by Abdullah Ali. Jakarta: PT. Serambi Ilmu Semesta, 2011.

Yafie, Ali. Kemitraan Perempuan-Laki-laki: Agama Islam di Bainar, Wacana Perempuan dalam Keindonesiaan dan Modernitas. Yogyakarta: Cidesindo, 2011. 